\title{
Science Education and Sustainable Development in Nigeria
}

\author{
Omole Catherine Ohunene ${ }^{1, *}$, Ozoji Bernadette Ebele ${ }^{2}$ \\ ${ }^{1}$ Science laboratory Technology Department, Abubakar Tatari Ali polytechnic, Bauchi. Nigeria \\ ${ }^{2}$ Science Education Department, University of Jos, jos. Nigeria \\ *Corresponding author: catieomole@gmail.com
}

Received May 15, 2014; Revised July 18, 2014; Accepted July 27, 2014

\begin{abstract}
The content and years of basic education differs around the world. Unfortunately, low quality of education is often received in poor regions or in countries where resources are not properly managed. Quality education however leads to acquisition of relevant skills and knowledge required for sustainable development and could be achieved through formal and informal education. The key factor is for the knowledge to be relevant to the society and be able to solve the unemployment challenges for the economic empowerment of an ever-growing population. To achieve this in Nigeria, the relevant focal points for sustainable development must be identified and addressed. What are the key issues that have to be addressed in order to steer the country towards sustainable development? The non- formal aspect of education has to be looked into. Science and entrepreneurship education be strengthened, and admission policies unto relevant courses that address the societal needs be reviewed.
\end{abstract}

Keywords: science education, basic education, sustainable development

Cite This Article: Omole, Catherine Ohunene, and Ozoji, Bernadette Ebele, "Science Education and Sustainable Development in Nigeria.” American Journal of Educational Research, vol. 2, no. 8 (2014): 595-599. doi: 10.12691/education-2-8-6.

\section{Introduction}

Quality science education depends upon recognizing an affirmation of freedom of inquiry and expression of this commitment. Without freedom to inquire, the scientific enterprise would be ruled by intimidation rather than understanding through inquiry. If students are not assisted in developing sound investigative skills at a very early age, then there is no reason to believe that students will be able to think critically and scientifically as they grow older (Renner, Stafford \& Ragan, 1973). The skills of science may be learned easily if the students are given opportunities to explore and tensions surrounding evaluation are relaxed in their minds. Hands on activities must be encouraged as it makes learning of science more real and practical to the student, encouraging critical thinking and exploration, leading to a sustainable development.

\section{Science Education}

Science education is the field concerned with sharing scientific knowledge, and methods with people not traditionally considered part of the scientific community. Science education should be able to transform the typical teacher-centered classroom lecture into a discovery and problem-solving arena. This encourages creativity and originality. In order to achieve this, the students have to be actively engaged in finding problems and looking for the solutions (Renner, Stafford \& Ragan, 1973). This is not common in a typical Nigerian science classroom and has resulted in Nigeria being a country of dependence, being mainly importers rather than producers. Our teachers have to learn to carry the students along with much flexibility if science education is to lead to meaningful learning. There is a need for the curricula to address issues that are typical to our environment and culture, and then integrate science concepts to teach, and in this way, science education becomes more meaningful to the child (Otive, 2006). Science becomes less abstract and more practical. The teacher can help relax the teaching environment and students can make connections between learning science in school and applying them in daily life (Hull, 1999).

In an educational evaluation paper by Okpala (1993), there was emphasis made on government policies with respect to development of science education at all levels as documented in the National policy on Education 2004. It mentioned that at the primary level, science education be introduced and taught by specialist teachers of which practical, explanatory, and experimental methods be used in teaching. At the secondary level, science education be taught of which English, mathematics and biology are made compulsory for all students. At the tertiary level, more resources are devoted to science and technology education. Admission into the science and business courses be weighed in the ratio of 70:30, in favour of the science courses. It also encouraged the establishment of science based institutions such as polytechnics, 
monotechnics and trade centers. This is all in an attempt to improve the Nigerian scientist.

\section{Sustainable Development}

Sustainable development is actually a very broad concept to define because it is continuously evolving. It tends to investigate and emphasize the development of the present without compromising the future of the upcoming generations (Brundtland commission, 1987). Sustainable national development can be seen as a process of improving the range of opportunities that will enable people to achieve their aspirations and full potential over a period of time while maintaining the resilience of economic, social and environmental systems. Basically it involves a knowledge base which revolves round three basic concepts which are the economy, the environment, and the society. The members of a society are financially empowered and responsible to not damage the environment so that our children's future is not compromised (McKeown,. 2002).

While many nations around the world have embraced the need for education to achieve sustainability, a lack of vision and awareness has impeded progress in Nigeria, which can be partially attributed to lack of planning, proper supervision and implementation of well designed policies. By addressing these critical issues, the Nigerian government can prevent or reduce delays or derailment of sustainable development projects and ultimately attain sustainability. To achieve this in Nigeria, the relevant focal points for sustainable development must be identified and addressed. What are the key issues that need addressed in order to steer the country towards sustainable development?

\section{Nigerian Peculiarity}

Teaching sustainability and making it a part of our daily living is vital but how do we go about it? Integrating sustainability alone in the formal school curriculum as an additional subject may be perceived as another additional burden to be learnt and never practiced. But this may be one of the fastest ways to create awareness of the concept of sustainability for the upcoming generations. However, this will only be sustained if it is taught at all levels (Mukute, 2010; Hamiti and Wydler, 2014).

By expanding educational facilities, governments may be faced with a conflict in the use of resources: whether to promote primary schooling in areas which have been relatively neglected (and where demands may still not be strong), or to place more emphasis on building up technical and upper level skills in higher education; in other words, provision of greater equality of opportunity to press for efficiency to meet finite manpower needs (Callaway \& Cirusone, 1968). Even in areas where facilities are available, some children may not be able to take advantage of primary schooling because of inability to pay school fees. There are wide differences in the incidence of who pays for education; in some areas payments are made directly by parents and in other areas indirectly through taxes or through various combinations of fees and taxes. This burden of paying for education impinges with greater or lesser intensity depending on individual family incomes and ultimately on natural economic resource endowments. Even though the universal basic education is supposed to be free, who bears the cost for transportation to and from distant schools, feeding, school uniform fees, books, and stationary fees? This is an additional burden that some families cannot financially support in a large family setting (Otive, 2006).

Awareness has to go beyond the borders of the classroom to the larger population who have not gone through any formal education system and are also stakeholders that must understand these issues. Because Nigerians are lovers of entertainment and spend considerable time before their television sets, the values could be taught in the various indigenous languages by the public media through enlightenment programmes, dramas and films (Nnabuo, P.O.M \& Asodike, J.D. 2005).

Uncontrollable and unchecked population growth is another worrisome issue that is of growing concern to the Nigerian government. Nonetheless, observers note that the country's leadership is apparently becoming more aware of the need to initiate decisive measures to control the country's population which has been growing without a boost in resources for sustainable development (Buki, 2012). Signaling the thrust of the new Federal Government's policy shift, President Goodluck Jonathan urged Nigerians to brace up for an imminent legislation on birth control to prevent a looming population 'explosion'. Nigeria's current population projection as of July 2012 was about 171 million and the population is growing at an alarming rate of 3.2 per cent (National Population Commission [NPC]). "No meaningful planning is possible without dependable data and statistics," The president reiterated, warning against the use of population and other demographic issues to garner cheap political advantage and engender political discord (Buki, 2012). Nigeria has never supported birth control officially, either through a policy or a law, owing to its controversial nature and this applies to many countries of the world (Buki, 2012).

\section{Improving Basic Education}

Different Countries have varying definitions for basic education. For some, the ability to read and write is defined as basic education while some have to complete a particular class or obtain a type of certificate to qualify as having a basic education. However, in many countries the current level of basic education is too low, thereby severely hindering national plans for a sustainable future. In Nigeria, Basic Education comprises both the range of formal schooling as well as a wide variety of non-formal and formal public and private educational activities offered to meet the learning needs of groups of people of all ages. Thus basic education refers to early childhood and pre-primary education, primary education, the first three years of secondary education and basic and functional literacy for out of school children, youth and adults, as well as nomadic education for school age children of nomads and migrant fishermen (Olorunfemi, 2012). It may also include nomadic education as well as adult literacy. Nigeria happens to be a signatory to the Jometian declaration in 1990 of Education for all by the year 2000, and a member of the E-9 nations dedicated to 
the eradication of total illiteracy. The 2012 economic section of the United States embassy in Nigeria reported that the literacy rate was still very low (61\%) and that statistics show that out of 30 million children of school going age, only 10 million children are enrolled in primary schools. The literacy level in the country has steadily and gradually deteriorated, especially within the 15-24 years group. By 1999, the overall literacy rate had declined to $64.1 \%$ from $71.9 \%$ in 1991 . The trend was in the same direction for male and female members of the 15-24 years age bracket (Otive, 2006). The Education for all, EFA (2000) report further states the completion rate is 64\% while those that proceed to Junior Secondary Schools (JSS) were placed at $43.5 \%$. The EFT Technical report (2006), Fast track initiative for Education for all, FTI explains, significant challenges to be faced by high population countries. Five countries, namely India, Nigeria, Pakistan, Bangladesh and Ethiopia, account for nearly 40 percent of the out-of-school children in the world (EFA report 2006). The report suggested that this is overwhelming evidence that the vital literacy indicators have not improved.

Recent happenings in many regions of the world have further hindered the quality of education. For example, tsunamis and religious conflicts have forced the closure of schools for long periods. In Africa, many regions are disturbed by droughts or wars(East Africa Drought, 2011). In Nigeria particularly, flooding in recent times resulted in a compulsory holiday for many school children for a significant period of time, hindering school attendance (IRIN, 2012). The Northeastern part of Nigeria recently recorded a massive decline in school enrollment and attendance due to terrorist infiltration and insurgencies. The average attendance in schools is dwindling, and is a major source of concern. The impact of these issues delays development of short and long term sustainability plans for the country. Absence from schools highest among states in the Northeast and Northwest zones. $72 \%$ of primary age children never attended school in Borno state. This compares with less than 3\% in most southern zones (United States Embassy Education factual sheet, 2012).

Where interruptions of the school calendar are encountered, adjustments should be made to make up for lost time. Tents could be adapted as temporary classrooms to ensure continuity as survivors deal with life's challenges. Education of children of school going age in troubled areas can be taken over by the government by sending them to boarding schools in safer regions to maintain their educational pursuits. Non Governmental organizations (NGO'S) concerned with improving education can compliment government efforts. Access to education should never be denied. Curricula should include the all facets of sustainability and consider indigenous traditions, values and practices. Since sustainable development encompasses environment, economics, and society, people need some form of basic education to be able to comprehend the issues at stake in terms of present and future sustainable development.

\section{Training}

A country with a large number of unskilled workers will have limited development options. Indeed, if communities and nations hope to identify and work towards sustainability goals, they must focus on skills, values, and perspectives that encourage and support public participation and community decision making. To achieve this, basic education must be restructured to address sustainability, and expanded to include critical-thinking skills, skills to organize and interpret data and information, skills to formulate questions, and the ability to analyze issues that confront communities (McKeown, 2002). The citizens should be well informed to make wise decisions for both their private lives, and for their community by understanding the issues and how candidates stand during elections. Nigeria has a large number of out of school children and young adults with limited literacy and numeracy skills who have little or no hope of ever joining the formal work force (United States Embassy in Nigeria, 2012). The NGO's, media outfits, and adult literacy centers have to be involved in the enlightenment to inform this group about sustainability,

Nnabuo \& Asodike (2005) cited Mbagwu and Nwakire to define non-formal education as any organized educational activity or training activity for school dropouts, for illiterate rural and urban adults, for youths, women, or individual workers aimed at improving their employment and income earning potentials, or providing them general education that in some cases may help them re-enter the formal education system.

The goal of non-formal education is to improve living conditions for beneficiaries and alleviate poverty in the community. The mass media should support a campaign to raise public awareness of sustainability, convey information on indicators of sustainable development (peace, equity, and justice), and encourage individuals to adopt practices that will promote development in their daily lives. This information could be provided through radio, television, films, and print media such as newspapers, magazines, and periodicals (Nnabuo \& Asodike, 2005).

\section{Science and Entrepreneurship Education}

In a bid to eradicate poverty, curtail the high unemployment rate, and empower graduates of Nigerian tertiary institutions with suitable employability skills, the federal government through the Ministry of Education in 2007 made entrepreneurship development study a compulsory course requisite for graduation. The essence was to offer students a well rounded education in terms of knowledge, skills, techniques and values needed to produce self-reliant individuals who can compete favourably anywhere in the world. It is therefore desirable for every child to have some idea of a business enterprise market (Jimah, Jimah \& Onuwka, 2010).

Years after the introduction of this initiative, no proper evaluation has been done to assess the level of skill and competences acquired by the students in view of the enormous resources voted into the programme. It is important to determine how equipped the students are to in order to create a niche for themselves, given little impetus in the labour market (Jimah, Jimah \& Onuwka, 2010). The primary aim is to boost small and medium scale enterprises, create wealth, and empower Nigerian youths. 
One observation (of formal education products) is that students graduate without knowing how to think in whole systems, how to find connections, how to ask questions, and how to separate the trivial from important. Now more than ever, we need people who think creatively and who understand systems, connections, patterns, and events root causes (Orr, 1992). Educators need to ensure the interconnection between the environment, economy and social structures becomes an integral part of formal education, starting with the pre-primary and continuing through primary and secondary school and through training at the tertiary institution, and at the professional level (Orr, 1992).

\begin{tabular}{|c|c|c|c|c|}
\hline Issues & Economic & Society & Environment & Combined \\
\hline $\begin{array}{l}\text { Environmental } \\
\text { issues: } \\
\text { i). Forest } \\
\text { preservation \& tree } \\
\text { felling issues } \\
\text { ii)Refuse disposal } \\
\text { and waste } \\
\text { management }\end{array}$ & $\begin{array}{l}\text { Empowers a few } \\
\text { minority financially. } \\
\text { ii) An area highly } \\
\text { underrated by the people } \\
\text { as an economic venture. }\end{array}$ & $\begin{array}{l}\text { A source of cooking energy for the people. } \\
\text { Alternative ways of cooking energy } \\
\text { should be explored. } \\
\text { ii) Has led to poor hygiene, as it is not a } \\
\text { patronized business venture and govt } \\
\text { participation is limited. }\end{array}$ & $\begin{array}{l}\text { Detrimental to the } \\
\text { environment. desert } \\
\text { encroachment and a } \\
\text { major erosion source. } \\
\text { ii) poor refuse disposal } \\
\text { techniques. Leads to } \\
\text { health epidemics. }\end{array}$ & $\begin{array}{c}\text { Harmful practice that } \\
\text { should be discouraged as } \\
\text { an economic } \\
\text { empowerment venture. } \\
\text { Tree planting be } \\
\text { encouraged. } \\
\text { ii) An area that needs } \\
\text { patronage by the govt and } \\
\text { private ventures. }\end{array}$ \\
\hline $\begin{array}{c}\text { Knowledge } \\
\text { i) Basic Education } \\
\text { made assessable to } \\
\text { all. Science } \\
\text { education } \\
\text { encouraged. } \\
\text { ii). Empowering the } \\
\text { illiterate adults with } \\
\text { adult literacy skills } \\
\text { iii) Population } \\
\text { education }\end{array}$ & $\begin{array}{l}\text { Has long term gains } \\
\text { This is a tool to assess } \\
\text { knowledge, which is } \\
\text { power. Communication } \\
\text { will also be } \\
\text { strengthened. } \\
\text { Leads to proper family } \\
\text { management }\end{array}$ & $\begin{array}{c}\text { This is the major tool for empowerment of } \\
\text { the people to engage in sustainable dev } \\
\text { programmes. } \\
\text { Broadens people's breadth and quality of } \\
\text { thinking } \\
\text { Overpopulation issues. Govt. cannot plan } \\
\text { adequately for an unknown population. }\end{array}$ & $\begin{array}{l}\text { Will help make the } \\
\text { right choices that will } \\
\text { be positive for the } \\
\text { environment. } \\
\text { Makes one more } \\
\text { conscious } \\
\text { environmental } \\
\text { interactions } \\
\text { It leads to } \\
\text { overstretching of } \\
\text { facilities. }\end{array}$ & $\begin{array}{l}\text { Will have citizens with } \\
\text { open minds, problem } \\
\text { solvers rather than being } \\
\text { the problem in the } \\
\text { society. } \\
\text { An overpopulated country } \\
\text { cannot develop due to } \\
\text { improper planning. }\end{array}$ \\
\hline $\begin{array}{l}\text { c. Skills } \\
\text { i). Specific job skill } \\
\text { acquisition. }\end{array}$ & $\begin{array}{l}\text { Will lead to poverty } \\
\text { reduction and } \\
\text { economically empower } \\
\text { the immediate family }\end{array}$ & $\begin{array}{l}\text { Answers the needs of people in the non- } \\
\text { formal sector to learn a trade. Poverty } \\
\text { reduction is achieved. }\end{array}$ & & $\begin{array}{l}\text { A people that are } \\
\text { positively engaged in } \\
\text { viable activities. }\end{array}$ \\
\hline $\begin{array}{c}\text { Values } \\
\text { Patriotism }\end{array}$ & $\begin{array}{l}\text { Long term gains } \\
\text { achieved resulting in } \\
\text { economic } \\
\text { empowerment. }\end{array}$ & $\begin{array}{l}\text { Love and care for one another is } \\
\text { developed.. Love for the country is } \\
\text { strengthened. respect for life, religion and } \\
\text { culture of the people are a part of the } \\
\text { people. Examination malpractice } \\
\text { involvement will be drastically reduced } \\
\text { resulting with a competent workforce. }\end{array}$ & $\begin{array}{l}\text { Brain drain is halted, } \\
\text { and educated citizens } \\
\text { stay home to } \\
\text { contribute to their } \\
\text { nation's development. }\end{array}$ & $\begin{array}{l}\text { Will build patriotism in } \\
\text { the citizens, to enable } \\
\text { them to love their country } \\
\text { and do the right things. } \\
\text { Responsible citizens are } \\
\text { bred. }\end{array}$ \\
\hline
\end{tabular}

\section{Conclusion}

In conclusion, many challenges abound when it comes to science education for sustainable development. The concluding table shows the researchers views on where intervention strategies could be applied. These strategies can be broken down into teachable units for a student, managed as priority projects by NGO's, or taken up by the film industry and films through the use of jingles and publicity concerning the issues to be highlighted. These various methods will enable the sustainability message to be communicated to more people in the society. Target dates of achieving each goal can be set and evaluation machineries be placed to check progress of attainment of each stated goal. Finally, good quality education is essential in achieving the level of economic growth required to tackle poverty and make sustainable development a reality.

\section{References}

[1] Brundtland Commission. (1987). Report of the World Commission on Environment and Development: Our Common Future (Brundtland Report) http://www.cfr.org/economic-

\subsection{Some key issues for a sustainable development.}

Many challenges have been discussed above. In order to chart a way forward, some key issues that could steer the country towards a sustainable development are described below:

\subsection{Identified Issues of Sustainable development in Nigeria}


[9] Jimah, M.S, Jimah, K.Q. \& Onwuka.E. (2011). Skill and Competency Acquisition through symbols-based projects of CEDAP, Auchi Polytechnic, Auchi: a synthesis.msj libraries. msjlib.wordpress.com/2011/09/10/skill-and-competencyacquisition/ (Accessed July. 11, 2014).

[10] McKeown, R. (2002).Environment Society Economy Education for Sustainable Development Toolkit Version 2 http://www.esdtoolkit.org (Accessed July. 11, 2014).

[11] Mukute, M. (2010).Integrating Sustainability in School Curriculum and practice: The case of the schools and colleges permaculture programme in Zimbabwe. ICID+18, Fortaleza Ceará,

Brazil

http://www.icid18.org/files/articles/938/1279514283.pdf (Accessed. July 14, 2014).

[12] Nnabuo, P.O.M \& Asodike, J.D (2005). Exploring Education as a tool for sustainable Development in Nigeria. European Scientific Journal May edition vol. 8, No. 10. ISSN: 1857-7881 (Print) eISSN 1857-7431. 1.
[13] Okpala, P.N. (1993) Reforms in Science, Engineering and Mathematics Education. An Educational Evaluation, National Examination Council office, Minna.

[14] Olorunfemi, M.O.A. (2012). The Education For All assessmen (EFA): country reports Nigeria. World Education Forum National assessment coordinator, Federal Ministry of Education, Abuja.

[15] Orr, D. (1992). Ecological Literacy: Education and the Transition to a Postmodern World, (SUNY Series in Constructive Postmodern Thought). Albany, NY, SUNY Press.

[16] Otive, I. (2006) The State Of Education In Nigeria. A keynote address delivered at a roundtable organised by civil society action coalition on education for all (csacefa) on $3^{\text {rd }}$ july, 2006

[17] Renner, Stafford \& Ragan, W.(1973).Teaching Science in the Elementary School, Harper \& Row, pp. 88, 89.

[18] United States Embassy Education factual sheet. (2012). DOI=(http://photos.state.gov/libraries/nigeria/487468/pdfs/Januar yEducationFactSheet.pdf).Assessed July, 2014.

[19] Universal basic Education commission. (2014) Ubeconline.com (Assessed July 2014). 